\section{Géneros}

Multidisciplinary Journal of Gender: Studies
Hipatia Press

www.hipatiapress.com

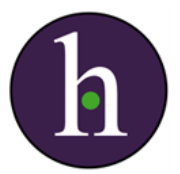

Instructions for authors, subscriptions and further details:

http://generos.hipatiapress.com

\title{
Paying for the Party: How College Maintains Inequalities
}

Ana Vidu ${ }^{1}$

1) University of Barcelona. Spain

Date of publication: February $25^{\text {th }}, 2016$

Edition period: February 2016 - June 2016

To cite this article: Vidu, A. (2016). Paying for the Party: How College Maintains Inequalities [Review of the book]. Multidisciplinary Journal of Gender Studies, 5(1), 958-960. doi: 10.4471/generos.2016.1976

To link this article: http://dx.doi.org/10.4471/generos.2016.1976

\section{PLEASE SCROLL DOWN FOR ARTICLE}

The terms and conditions of use are related to the Open Journal System and to Creative Commons Attribution License (CC-BY). 
GÉNEROS -Multidisciplinary Journal of Gender Studies Vol. 5 No.1 February 2016 pp. 958-960

\section{Review}

Armstrong, E. A., \& Hamilton, L. T. (2015). Paying for the Party: How College Maintains Inequalities. Cambridge (MA): Harvard University Press

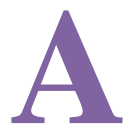

lthough being considered places with high academic reputation, in recent times, North American universities are also in vogue due to protests and students mobilizations claiming their rights. These demands not only include equality and social justice, but also, the university commitment for preventing and acting for instance against gender violence, as well as for the usually notorious atmosphere on what is called the "college parties" or the "Greek life". Indeed, this debate is being spread all over the country, as most universities' policies and debates are focused on prevention and response in front of incidents occurring at university parties, as these are playing an important piece of college life. In this context, Paying for the party shows up at the very moment, and it can perfectly be illustrated as an American higher education social class analysis "from inside". The authors, Elizabeth Armstrong and Laura Hamilton, both renowned Professors of Sociology at prestigious universities (University of Michigan and University of California-Merced, respectively), spent one year living and discussing with fifty-three women occupants of the residence hall of a large public North American university, the Midwest University (MU).

This book is the culmination of an ethnographic and longitudinal approach used on analyzing these women's trajectories during five years; collecting more than two hundred interviews and almost two-thousand pages of fieldwork notes. Considering the professional, party and marital options, Armstrong and Hamilton describe the different paths which most women tend to follow once in college, mainly according to their socioeconomic status. Thus, the "party culture" seems impossible to avoid; but at the same 
time, suitable for certain women. Following the paths chosen by the interviewed women to achieve university's expectations, the authors distinguish two different student profiles: the ones coming from a very favorable economic context; and on the other hand, those women whose families cannot afford their college tuition. According to this dichotomy, the university system do not prepares all students equally, it even makes difficult the inclusion of everybody in all social activities. These intrinsic mechanisms are maintaining the "systematically disadvantages" for the already less privileged students.

In the first chapter, the relationship between Hannah and Alyssa shows how the women's class background as well as their individual orientations in college are setting differently their college experience. Being a low-income student, Alyssa does not share the same activities as Hannah, as going out and spending money. The case of Amy, exemplifies some of the consequences of this cultural and economic difference: "Amy was very lonely and nearly broke down in tears". On the other hand, and broadly discussed on the second chapter, the "party dorms" and the "Greek Life" are shaping the college experience for those women and men known as belonging to a social orientation in which having "party reputation" is considered to fulfill the best life's time. American colleges tend to have an entire organizational infrastructure around the "party pathway"; fraternity and sorority houses concentrate the social resources on campus: "even the academic requirements at MU were arranged according to the Greek social calendar".

The next focus of the book is aiming to deeper understand the context around this infrastructure. Chapter three and four are pointing out the peer cultures, emphasizing how these are hierarchically constituted. Competing for status in a party scene ("affluent parties dominate the floor") may create a conflict between the so-called "socially oriented students" and the "resource rich party pathway". Thus, being recruited in a sorority may depend on ties, friendship and physical aspect. At the same time, this reality involves social isolation consequences. For example, Emma, from a middleclass background is being an "outlier".

In the next chapters, Hamilton and Armstrong discussed experiences on socialites, wannabes and fit within the party pathway, showing for instance how some women have to fight hard for a mobility pathway (for example to 
accomplish a "social and erotic status"). The author's reasoning also explains the case of the downward mobility. Finally, last chapters discuss empirical evidences on how universities do not close the gap between the more and less privileged women. So, it should be reengineered bringing attention to all students, overcoming all obstacles. The dismantling the party pathway domination and eliminating the "Greek life" are some of the solutions provided by the authors.

Paying for the party pretends to spread social awareness about college life shedding light on the social role of universities and how they are focused on reproducing socioeconomic situations rather than overcoming them. With this book, Armstrong and Hamilton add a key contribution in line with their well-known scientific research in areas as gender, sexuality and higher education.

Ana Vidu, University of Barcelona ana.vidu@ub.edu 